\title{
Setting Priorities in Pediatric Research: Who Is Responsible?
}

\author{
VIJAYA L. MELNICK ${ }^{(17)}$ \\ University of the District of Columbia, Department of Biology, Washington, D. C., USA \\ Symposium: Frontiers of Pediatric Research and the Shaping of Public Policy
}

The place of children in American society is repleate with contradictions. Commenting on the child-centered and oriented nature of our society, Phillip Wylie called it "America: The world's first pediarchy." The media and the advertisement that push various products, whether they be directed towards children or not, present the concept that we adore the child. At social gatherings, we discuss our children ad infinitum, sing their achievements, express concern when they do not receive, as we see it, the best in education or recreation.

However, if we look at children and American society in another way, there is reason for alarm and reason for distress. In a speech, delivered a decade ago before the Senate of the United States, Vice President Walter Mondale (12), then a Senator said "Our national myth is that we love children, yet we are starving thousands. Other thousands die because decent medical care is unavailable to them. The lives of still other thousands are stifled by poor schools and some never have the chance to go to school at all. Millions live in substandard and unfair housing in neighborhoods which mangle the human spirit. Many suffer all of these mutilations simultaneously."

Current statistics (14) show that what Senator Mondale said more than a decade ago is still true. We have made little, if any, progress. For today, 17.6 million children in the United States live in debilitating poverty in families with incomes below the poverty line. Ten million children or one out of seven under the age of 16 receive no regular medical attention. Thirty-three percent of all children under the age 17 , one of every three, have never seen a dentist. More than seven million children under the age of 19 have some physical handicap, and of these $45 \%$ receive no care at all.

The state of health in this nation as summarized in the Department of Health, Education, and Welfare publication "Health United States 1979" (8) reports that we rank 13th among the countries reporting the lowest infant mortality rates. Even though overall infant mortality rates have improved over the last decade, the rates for particular groups and communities in the United States have shown little change. For example, blacks suffer about double the infant mortility as compared to whites. Although New England and the Pacific states report low infant mortality rates, the East South Central regions show a markedly high rate. Maine, for example, reported a rate of 11.2 as opposed to 27.2, reported in Washington, D. C. It is estimated that there are over one million youth who are the victims of child abuse and neglect. Disability due to illness or accident is $50 \%$ higher for the poor than for the rest of the population. Avoidable or curable diseases such as untreated middle ear infections, iron deficiency anemias, lead poisoning, and malnutrition are all so prevalent among the poor that these are sometims referred to as "diseases of poverty." Furthermore, nearly one million adolescent girls, one in ten, become pregnant each year. The majority of these girls go through with their pregnancy and keep their babies. We have then a situation where children are caring for children. Pregnancy is seen as a major factor for school dropouts among this age group, and that in turn has a critical and negative effect on future chances for educational training and economic stability.

These alarming statistics and conditions would lead us to acknowledge that children do not figure very high in our national priorities. Even though most of us on an individual and personal basis love, cherish, and protect our children, these same attitudes have not been transferred to a national code of behavior. The distressing plight of many children in this country points to a national attitude showing little concern for the tragic consequences of what happens to our children, and that has to be described as malignant neglect. Such an attitude, which foolishly risks our most priceless future resource, namely our young, is sure to reap a heavy toll on this nation, both socially and financially. As the eminent pediatrician and child advocate George Silver (15) points out, "neglected children become sick, handicapped, socially dependent adults who need social welfare support, and who need expensive hospitals, convalescent homes, and rehabilitation facilities."

It is clear that many of the problems that contribute to the ill health and non-well-being of our children, require a regimen that goes beyond that offered in traditional clinical medicine. If we are to mount an attack on these problems, we must accept the responsibility to alter and mold the forces that are properly regarded as the prime factors in the etiology of these disorders. My thesis today is that this battle requires a focusing of research efforts that will aim them at provoking a change from the status quo. That, in turn, requires a dovetailing of pediatric research of the highest scientific merit, dedicated patient- and child-oriented clinical practice along with a deep awareness of the social, political, and policy relevance of such work.

I further contend, that the reason why we are in this deplorable plight is: not wholly because we lack adequate and appropriate knowledge and information; not wholly because we lack needed resources; not wholly because we sometimes lack commitment and awareness; nor entirely because that at times we become indifferent and negligent, but it is because of the most important, and at once the most damaging, reason which is that we lack leadership. No one has come forward to accept the responsibility for our children's cause.

If this vacuum of leadership is to be filled, the process must begin by building a strong and dedicated child advocacy group, a group that is widely based and one that will bring together a dynamic partnership of citizen activists who can speak to the needs of the consumer and progressive intellectuals who can fashion such needs to effective strategy. Only such a coalition will be able to transform the issue of child health into the realm of social policy.

Pediatric research includes, as I see it, the generation of knowledge and the development of strategies that aims to achieve the well-being of all children. I shall examine the place of such research from the broad perspective of the impact of biomedical research and public policy. In doing so, I shall try to discuss why we suffer from a lack of leadership and consider the major impediments that we must be cognizant of and that we must overcome if we are to seriously move towards the goal of making our children's health and welfare our nation's top priority.

Setting priorities in pediatric research, I would assert, is the singular and special responsibility of the pediatric research scientists. In your dual role as researchers who have the knowledge, detachment, and necessary skills in the field and as physicians 
who have the social and ethical commitment of working for the welfare of your present and potential patients, there is no other group more eminently qualified than yourselves to identify critical problems and develop appropriate strategies to surmount those problems. By doing that you will demonstrate that the entire population of children is deserving and worthy of your dedication and advocacy, just as the clinician necessarily considers himself the strong advocate of his patient in a one to one relationship.

That will be the first step towards filling the gap of leadership. Such leadership, like any other, will not be lightly achieved or won. It will most certainly require a clear and cogent self-evaluation and assessment.

As President Kennedy said once before, "If we are to walk a thousand miles, let us begin by taking that first step."

Assessing the role of physicians and biomedical scientists inpublic policy, Robert Alford (1) in his perceptive and scholarly analysis on "Health Care Politics" observed, "The physicians and biomedical researchers are not in the vanguard proposing reforms, except when their powers and perogatives are theatened by others." The reason for such behavior (11) let me suggest, may be due to the following:

1. The training and education we receive discourage us from exploring the policy implications of research. In research training, the ideal is achieved when the researcher has his own laboratory, has large resources and freedom to select problems, and is relatively free from teaching or other responsibilities such as service and administration. The same environment might, however, remove the researcher further away from day-to-day contact with everyday patients and issues that are important in the delivery of care. In other words, such a researcher might become increasingly reluctant to consider routine cases that are external to his special research interest and therefore become not too concerned as to how his research could be translated to practices in routine care.

2. A resistance on the part of biomedical researchers and educators to fully reconsider traditional paradigms and familiar methods of operation, in other words, a reluctance to swim against the tide. Although the individual doctor-patient relationship served for centuries as the single institution mediating the allocation of medical knowledge to different segments of our society, two forces which were born in the 19th century and intensified in the 20th century have led to the increasing politicization of the delivery of health care. In America, these forces must be seen as having been enhanced by the work of Abraham Flexner (5) whose 1910 report on medical education exposed the unprofessional preparation offered in the majority of American medical colleges. His fourth bulletin led to the reorganization of medical education which made possible, in a large way, the advancement of science and medicine. Flexner followed his critical efforts with a life-long career devoted to generating support for medical schools which had reformed their structures. Yet, ironically the very forces which were encouraged by Flexner's efforts have created the need to transform the institutions he nurtured. In the "Handbook for Change" issued by the student American Medical Association, the editors dedicate the volume to their patients and to Abraham Flexner, "whose work so standardized medical education that any real change becomes revolutionary." Scientists and physicians who claim their field as an inviolate domain often lightly skip over the fact that Flexner was neither a bench scientist nor a physician. Rather, he was an educator who had studies at Harvard, Johns Hopkins and various German Universities. His access to the minds of physicians was enhanced by the fact that his brother was the head of the Rockefeller Institute. Flexner's study of medical colleges was commissioned by the Carnegie Endowment for teaching. His evaluative and objective report must have been regarded by the then directors of medical colleges with the same love and affection which the Board of Directors of General Motors has for reports from Ralph Nader.
3. Professional and academic advancement criteria do not include public policy activity. Researchers feel that no amount of public policy activity will contribute anything to their professional status. In their vocabulary, the term "real work" has but a single meaning--work in the laboratory or research clinic. Many feel that science and politics (even the politics of biomedical policy) are incompatible pursuits.

4. A widely held belief that scientific eminence is a sine quo nom of policy influence. Researchers often pick Nobel Laureates, members of exclusive professional organizations, heads of academic departments or deans when they are asked to name someone who has policy influence. The fallacy here is that eminence does not automatically mean being articulate or knowledgeable in the public policy arena. Legislative aides often wonder as to how some who come with mile long credentials and degrees manage to be so totally incomprehensible and out-of-context.

Commenting on the communication gap between the scientist and the public Senator Edward M. Kennedy (9) in a speech before the International Congress of Cell Biology said “...the scientist and the citizen often do not speak the same language, or at least do not engage in a useful exchange of views. Sometimes the scientists speak down to the layman in technical language that the latter cannot understand. It is tremendously important to strive to explain the implications of scientific work clearly." He goes on to say,

The biomedical research scientist has not told his story well to the public. He has not adequately fostered the kind of educational process which would inform the public as to the nature of science and its mode of operation. He has not made clear to the public the great contributions of biomedical research to improving public health. That is where the payoff is for the layman and that is what will assure continued support for research. The second public challenge facing the research community is not only to educate but to demonstrate its cooperation in helping solve society's problems in the important area between the laboratory and the clinic. The challenge is there for biomedical scientists-whenever feasible-to help translate their basic knowledge into useful applications. This will work wonders in building continued public support for research.

This makes it clear that those of us who hold the mistaken point of view that discussions on developing strategies to garner support for biomedical research has little relationship with what happens at the delivery end, such as hospitals and community clinics, will not be doing themselves or the enterprise of research a favor.

Pragmatism and current realities compel us to acknowledge that issues and allocations for science come within a sociopolitical agenda. As Philip Handler (7), President of the National Academy of Science observed,

It is simply naive to suggest that science is as apolitical as it is amoral. Once the enterprise assumed its multi-billion dollar dimensions and was accepted as a proper charge on the public purse, science entered the political arena, in the sense that it is the relation between a given scientific sub-discipline and its interaction with social and political values that determines relative resource allocations.

If many of the biomedical researchers are lost in the tangle between their own jargon and a so-called tunnel vision when attempting to address the broad questions of biomedical policy, we cannot take comfort in the knowledge that the government as represented by the Department of Health, Education, and Welfare will provide the necessary directions and leadership.

Commenting on the United States Department of Health, Education, and Welfare, the New York State Rockefeller Committee (13) remarked that the Department of Health, Education, and Welfare has been "too politically defensive and not sufficiently administratively assertive. Too frequently, it reacts to individual 
congressional initiative and, in the absence of an overall health strategy of its own, fails to provide leadership. Many of its programs address old issues which have been inherited from earlier days and not been retooled to keep abreast of contemporary needs. Overlays are put on overlays and instead of reform and new structure, old programs are continued in their old style while new ones are added as needed-and as legislative expediency permits." Oftentimes this leads to the following frustrating predicament. Legislations or congressional intents as expressed in budget appropriations committee hearings which try to establish new principles of operation and which are explicitly designed to change the system, more often than not, get distorted and transformed by the agency in ways which reinforce present methods of operation, present pet programs of the particular administrators, and, therefore, inevitably, the present system. The result being that bold new programs become timid old ones.

The question must then be asked, can we look to our elected representatives, namely the United States Congress, for initiative and leadership. The Congress is the most open public arena that can substantially affect the destiny of this nation, but the very openness of the Congress, which is its major strength, is ironically also its major weakness. The members of this august body know that they can never get too far out in front of their constitutents.

A recent survey (16) conducted on the attitudes of the American public on matters of health and health care allocations reports that a clear majority of $60 \%$ were concerned about the preventive approach to health care, but when asked about their principal health worry, an overwhelming number of Americans indicated that they are worried about catastrophic illness such as cancer and heart disease rather than the more mundane, but possibly serious ordinary illnesses. Only $11 \%$ mentioned "everyday" illness as a principal health worry. The result points perhaps to the reason why biomedical research allocations are for the most part designated towards research on categorical diseases. Senator Kennedy's observation (9) is very relevant here when he says,

...there is little doubt that what the taxpayer expects from this investment (meaning investment in biomedical research) is the ultimate conquest of diseases--specifically those diseases whose names he knows and whose consequence he fears. This may represent a simplistic view of the process whereby we translate research into applications, but it is the prevailing view in the country and the Congress. And it is a view with which we in public policy positions have to contend.

The special interest groups, such as the disease of the month club, the various organizations involved in the cancer crusade, and other such specially focused lobbying groups have also done their part in reinforcing the view of the Congress towards categorical disease programs and patterns of resource allocation. This response is to be expected from the Congress because in the world of the politician the electoral process is the central mechanism for generating authority and that involves acquiring a skill for interpreting complex legal issues in simple, easily understood terms. A politician increases his power by widening his constituency, and this means articulating his position on issues, not only in a clear and understandable manner, but saying it in a way that reflects, what he perceives, as the sense of the public.

There is yet another reason why the Congress may not be a likely leader in setting priorities for preventive programs as opposed to rescue efforts. Even though the Department of Health, Education, and Welfare "Forward Plan for Health" (6) holds "only by preventing disease from occurring, rather than treating it later, can we hope to achieve any major improvement in the Nations health." this recommendation is clearly at odds with our budgetary allocation policies. For example, in 1976 (10), expenditures for health amounted to $11.4 \%$ of the federal budget, when that amount of 42.4 billion dollars is assigned to four major determinants of health, i.e., human biology, life-style, environment, and the health care system, the results are striking: $91 \%$ went to the health care system, $5 \%$ to environment, $3 \%$ to human biology, and $1 \%$ to lifestyle. James Childress (4) offers an ethical perspective for this in his article on "Priorities in the Allocation of Health Care Resources," he says "our society often favors rescue or crisis intervention over prevention because of our putative preferance for known identified lives over statistical lives." Statistical lives here refers to unknown persons in possible peril. He goes on to say "Allocation policies may be thought of as ways for the society to define and to express itself, its values, and its integrity. From this standpoint, it is possible to argue that rescue efforts should be important, if not dominant, in allocative decisions." Lawrence Becker (2) notes, "We have (rationally defensible) worries about the sort of moral character represented by people who propose to stand pat and let present victims die for the sake of future possibilities. One who can fail to respond to the call for help is not quite the same sort of character as one who can maximize prevention."

Ironically, in their one-on-one practice, the pediatric clinicians stress prevention; that same point of view should be transformed to the public arena where changes on broader policies will foster preventive policies and focus on the total wellbeing of our children.

The problem of assessing the impact of decisions relating to the resources which must be put aside to ensure that there is enough of the health pie to go around touches on every level of our political life from the attitudes of voters towards increased taxation to our relations with foreign nations. Yet, grappling with this problem forces us to confront a seemingly insoluble dilemma. How much of our resource, which seems to become more and more scarce as demands increase, should be allocated, for example, towards delivery of health services as opposed to the allocation for: (1) research on categorical diseases; (2) preventive medicine which includes a large part of pediatric research; and (3) the exploration of the general field of biology to generate fundamental knowledge that might, in the future, lead to a better understanding of human reactions, behavior, and the etiology of the now baffling diseases? That is a challenge facing not only the United States but the world.

What I have presented to you through this paper is the fact that biomedical scientists, as a rule, have not taken an activist role in the formulation of public policy, but that is not to say that there are no biomedical scientists who are activists. Surely, there are those among you who have shown an expressed interest and demonstrated ability to influence and shape public policy. It is then the responsibility of such an active group, such a cadre of pediatric research scientists to assume the leadership and serve as the necessary catalyst to bring together the research community, the clinicians, the public, and the policy maker under the united agenda of maximizing the health and welfare of our children. By doing that, you will demonstrate that there is a group of research scientist who are not only proficient in their fields of endeavor but who are responsive and responsible to the needs and welfare of mankind and sensitive to social complexities and inequities.

Let us then resolve to direct our creative energies and imaginative mental abilities not only to persevere at pursuading nature to yield her well-kept secrets but also to form a dynamic coalition with all other interested groups and individuals in an effort to initiate and sustain an effective dialogue to comprehend the problems that challenge science and society. Together, we can direct our energies to build a better tomorrow that will reflect a truly progressive society where public welfare and responsibility on the one hand and scientific purpose and goals on the other need no longer be divergent or at odds.

Let me close by reading a line from Albert Einstein, the acknowledged and quintessential scientist of this century, who was also an activist and a humanist. He said, "We exist for our fellowmen-in the first place upon whose smiles and welfare all our happiness depends and next for all those unknown to us personally but to whose destiny we are bound by the tie of sympathy. 


\section{REFERENCES AND NOTES}

1. Alford, R: Health Care Politics. (The University of Chicago Press, Chicago, IL, 1975)

2. Becker, L. C.: The Neglect of Virtue. In: H. H. Fudenberg, V. L. Melnick: Ethics. pp. 110-22 (1975)

3. Biomedical Scientists and Public Policy. pp. 1-14. (Plenum Press, New York, 1978).

4. Childress, J F.: Priorities in the Allocation of Health Care Resources. Soundings. 62: 256 (1979).

5. Flexner, A: An Autobiography. (Simon and Schuster, New York, 1960).

6. Forward Plan for Health: FY 1979-81. United States Department of Health, Education, and Welfare. Public Health Services p. 15 (1976).

7. Handler, P.: In defence of science. Fed. Proc.. 31: 1571 (1972).

8. Health United States 1979. United States Department of Health, Education, and Welfare. Public Health Services Washington, D. C. (1980).

9. Kennedy, E. M.: Biomedical Science in an Expectant Society Speech at the International Cell Biology Congress, Boston, MA, Sept. 3, 1976.

Copyright (C) 1980 International Pediatric Research Foundation, Inc. $0031-3998 / 80 / 1412-1295 \$ 02.00 / 0$
10. Koleda, M. S., et al:: The Federal Health Dollar: 1969-1976. National Planning Association Center for Health Policy Studies, Washington, D. C. (1977).

11. Melnick, V. I., and Melnick, D.: The silent elite: biologists and the shaping of science policy. In: H. H. Fudenberg, V. L. Melnick: Biomedical Scientists and Public Policy. pp. 1-14 (Plenum Press, New York, 1978).

12. Mondale, W. F.: Justice for Children. Congressional Record Senate, pp. 4050540518. Dec. 9, 1970.

13. Preliminary Report of the Governor's Stcering Committee on Social Problems on Health and Hospital Costs, p. 33, Apr. 15, 1971.

14. Report to the President: United States National Commission for the International Year of the Child, (Government Printing Office, Washington, D. C., 1980).

15. Silver, G. A.: Child Health. Aspen Systems Corp. (1978).

16. Yankelovich, Skelly, and White, Inc.: Family Health in an Era of Stress. The General Mills American Family Report 1978-1979, General Mills, Inc. (1979).

17. Requests for reprints should be addressed to: Dr. V. L. Melnick, Building 3i, Room SC06, National Institute on Aging, National Institutes of Health, Bethesda, MD 20205. 